\title{
Biological effects of four frequently used medicinal plants of Lamiaceae
}

\author{
Minireview
}

\author{
A. SRANCIKOVA ${ }^{1}$, E. HORVATHOVA ${ }^{1}$, K. KOZICS ${ }^{1, *}$ \\ ${ }^{1}$ Cancer Research Institute, Slovak Academy of Sciences, Vlarska 7, 8363 91Bratislava \\ *Correspondence: katarina.kozics@savba.sk
}

Received April 8, 2013 / Accepted May 31, 2013

\begin{abstract}
Cancer is one of the leading causes of death characterized by uncontrolled growth and spread of cancer cells. There are several hundred thousands of new cases of cancer worldwide. Clinical oncology is still challenged by toxicity and side effects of multimodal therapy strategies in which it is associated with poor prognosis for patients. There is an urgent necessity to develop novel therapy strategies and to utilize preventive potential of natural compounds. As the majority of anticancer drugs are of natural origin, natural products represent a valuable source for the identification and development of novel treatment options and chemopreventive mechanisms for cancer. This review is focused on the summary of published knowledges on the antioxidant and potential chemopreventive effects of biologically active substances present in the extracts of four plants of the family Lamiaceae (sage, thyme, rosemary and lavander) in different animal and in vitro systems. It is assumed that the chemopreventive and chemotherapeutic potential of natural compounds is the result of a combined action of several mechanisms.
\end{abstract}

Key words: sage, thyme, rosemary, lavender

Chemoprevention represents a promising strategy for cancer reduction. It is defined as a use of natural or synthetic substances to prevent cancer formation or cancer progression. The chemopreventive effects of natural compounds are based at least in part on the induction of defense system involving detoxification and antioxidant enzymes, on their anti-inflammatory activity, on the ability to interfere with the cell cycle and to induce apoptosis [1].

Many mechanisms of natural compounds action have been described in connection with anticancer activity. Great attention is devoted to intracellular signaling cascade as a target for natural compounds. Numerous plant derived compounds were evaluated as potent anti-tumorigenic agents in in vivo and in vitro systems. Multiple epidemiological studies and experimental carcinogenesis studies suggest a significant correlation between the consumption of foods rich in fruits and vegetables and the reduced occurrence of cancers [2].

Tumor formation is a multistage process involving series of events generally occurring over an extended period. During these processes, accumulation of genetic and epigenetic alterations leads to the progressive transformation of a normal cell into a malignant cell [3]. The plant extracts due to their unique features act at different levels and influence many cellular processes. They are becomming increasingly the main subject of chemotherapy research. Many researches are focused on the development of alternative approaches exploiting the potential of plant extracts in order to minimize the radiation dose through selective sensitivity of tumor cells and thus reduce the harmful effects of treatment [4].

Positive effects of Lamiaceae plants are attributed to the biologically active compounds which could reduce severe impacts of the environment or life style and eliminate side effects of drugs (Table 1). Chemopreventive activities of Salvia officinalis, Thymus vulgaris, Rosmarinus officinalis and Lavandula angustifolia presented in this review are summarized in Table 2.

In addition, plant extracts have other advantages, they are easily available, cheap and relatively safe with fewer side effects than synthetic compounds used in chemotherapy [5]. Currently, some plant extracts are in the stage of clinical trials and others were approved for use. 
Table 1. Antioxidant capacity, total phenolic content, and comparision of rosmarinic acid content in species from Lamiaceae, Papaveraceae and Lauraceae.

\begin{tabular}{|c|c|c|c|c|c|c|}
\hline Scientific name and family & Common name & Country/ place & Edible parts tested & $\begin{array}{c}\text { TEAC } \\
(\mathrm{nmol} \text { trolox/ } \\
100 \mathrm{~g} \text { of } \mathrm{DW})^{\mathrm{a}}\end{array}$ & $\begin{array}{c}\text { Total phenolic } \\
\text { content } \\
(\mathrm{g} \mathrm{GAE} / 100 \mathrm{~g} \text { of } \mathrm{DW})^{\mathrm{b}}\end{array}$ & $\begin{array}{c}\text { Content of } \\
\text { rosmarinic acid } \\
(\mathrm{mg} / 100 \mathrm{~g} \text { of } \mathrm{DW})\end{array}$ \\
\hline $\begin{array}{l}\text { Cinnamomum zeylanium } \mathrm{N} . \\
\text { (Lauraceae) }\end{array}$ & cinnamon stick & Indonesia & cortex & 107.69 & 11.90 & - \\
\hline $\begin{array}{l}\text { Origanum vulgare } \mathrm{L} . \\
\text { (Lamiaceae) }\end{array}$ & oregano & New Zealand & leaf & 100.67 & 10.17 & 2562.7 \\
\hline $\begin{array}{l}\text { Salvia officinalis L. } \\
\text { (Lamiaceae) }\end{array}$ & sage & New Zealand & leaf and branch & 51.89 & 5.32 & 2186.1 \\
\hline $\begin{array}{l}\text { Thymus vulgaris L. } \\
\text { (Lamiaceae) }\end{array}$ & thyme & New Zealand & leaf and branch & 38.07 & 4.52 & 681.1 \\
\hline $\begin{array}{l}\text { Rosmarinus officinalis L. } \\
\text { (Lamiaceae) }\end{array}$ & rosemary & New Zealand & leaf and branch & 37.8 & 5.07 & 1286.4 \\
\hline $\begin{array}{l}\text { Mentha canadensis L. } \\
\text { (Lamiaceae) }\end{array}$ & $\operatorname{mint}$ & Hong Kong & leaf and branch & 33.83 & 5.15 & 1908.5 \\
\hline $\begin{array}{l}\text { Ocimum basilicum } \mathrm{L} . \\
\text { (Lamiaceae) }\end{array}$ & sweet basil & New Zealand & leaf & 29.59 & 3.64 & 1086.1 \\
\hline $\begin{array}{l}\text { Papaver somniferum } \mathrm{L} . \\
\text { (Papaveraceae) }\end{array}$ & poppy & Dutch & seed & 0.55 & 0.04 & - \\
\hline
\end{tabular}

aTEAC, trolox equivalent antioxidant capacity. Data expressed as mmol of trolox equivalent/100 g of dry weight (DW). ${ }^{\mathrm{b}}$ Total phenolic content expressed as g of gallic acid equivalent (GAE)/100 g of dry weight (DW). (taken from Shan et al. [14])

Salvia officinalis. Salvia officinalis L. (common sage or garden sage) is a well-known medicinal plant used for centuries as a remedy for many diseases and as a cuisine matter. This plant of the family Lamiaceae, native to the Mediterranean region, is known for its antibacterial, antiinflammatory, antifungal, antioxidant and antiproliferative activities [6-9].

The bioactive components present in sage are terpenoids and phenolic compounds, the two major secondary metabolites of $S$. officinalis, that could be responsible for the pharmacological effects of this plant [8]. Among terpenoids, volatile oils have been largely investigated because of their broad range of applications in food, cosmetic and pharmaceutical industry [10]. Sage essential oil (EO) is a mixture of volatile compounds, predominantly of low molecular weight terpenes, containing more than 50 compounds, being $\alpha$ thujone, $\alpha$-humulene, 1,8-cineole, caryophyllene, camphor and borneol as the major constituents. The EO composition is highly influenced by genetic and environmental factors, climate conditions, season, and culture site $[10,11]$.

Sage contains also important bioactive terpenoids such as triterpenoid ursolic and oleanolic acids [12] characterized by high lipophilicity [13]. Both components manifested hepatoprotective, anti-inflammatory, antihyperlipidemic and antitumorigenic properties [13].

The majority of the phenolic compounds in Salvia species is almost exclusively rosmarinic acid with strong antioxidant activity. There is increasing evidence to suggest that the antioxidant activity of rosmarinic acid is due to the presence of two ortho-dihydroxy groups (catechol structures) [14]. Besides this phenolic acid, phenolic diterpenes such as carnosic acid and carnosol were found in sage and reported to possess strong antioxidant activities. Additionally, many other polyphenolic sage constituents were identified that could contribute to its antioxidant properties including caffeic acid as well as luteolin7-glucoside (Fig. 1) [15].

Thymus vulgaris. Thymus vulgaris $\mathrm{L}$. is a perennial herb indigenous which grows in central and southern Europe, Africa and Asia. It is rich in essential oils and antioxidant phenolic substances [16]. TV is widely used in folk medicine for the treatment of a variety of diseases including gastroenteric and bronchopulmonary disorders and in anti-worm, antispasmodic, carminative, sedative and diaphoretic remedies [17].

Quantitatively, the most important compounds in thyme are thymol and carvacrol, isoforms of the same monoterpene, which represent almost three-quarters of total volatiles, followed by terpenes, linalool (4\%), a-terpineol (2,4\%), 1,8-cineole (2,1\%), and borneol (2\%) [18]. As the main components of thyme, triterpenic acids [19] and phenolic compounds [20] were identified similarly as for sage.

Roby et al. [20] provided evidence that cinnamic acid was the dominant phenolic compound in thyme methanolic extract, since it constituted $28 \%$ of the total extracted compounds followed by the two principal flavonoids: apigenin (8\%) and luteolin-7-o-rutinose (7\%). Protective effect of T. vulgaris essential oil against aflatoxin B1-induced toxicity in rats has been reported by El-Nekeety et al. [21]. Aflatoxin B1, a well-known hepatocarcinogen, disturbs lipid profile in serum, decreases total antioxidant capacity, increases creatinine, uric acid and nitric oxide in serum and lipid peroxidation in liver and kidney accompanied with changes in the liver tissues. The oil alone did not induce any significant changes in the biochemical parameters, while the combined treatment showed significant 
Table 2. Summary of chemopreventive effects induced by extracts of Lamiaceae plants and their main constituents/components

\begin{tabular}{|c|c|c|c|c|}
\hline Plant species & Cells/animal models & Constituents & Chemopreventive effects & Refs \\
\hline \multirow[t]{7}{*}{ Sage } & - & Sage extract & Showed substantial antioxidant activity compared with BHT & {$[18]$} \\
\hline & Brain, liver homogenate in vitro & & $\begin{array}{l}\text { Inhibited lipid peroxidation and manifested high reducing } \\
\text { power }\end{array}$ & {$[23,25]$} \\
\hline & Human hepatoma HepG2 cells & & Prevented lipid peroxidation and GSH depletion & [25] \\
\hline & Different human colon cell lines & & $\begin{array}{l}\text { Protected DNA against oxidative and alkylating agents and } \\
\text { stimulated DNA repair }\end{array}$ & {$[27,28,29]$} \\
\hline & Human colon carcinoma HCT15, CO115 cells & & Induced apoptosis and inhibited MAPK/ERK phosphorylation & [9] \\
\hline & Human colon carcinoma HCT116 cells & & Suppressed NFKB activation and degradation of IKK & [32] \\
\hline & Human endothelial cells & & Inhibited angiogenesis due to anti-migratory effect & [36] \\
\hline \multirow[t]{7}{*}{ Thyme } & - & Thymol & $\begin{array}{l}\text { Exhibited the strongest antioxidant capacity of thyme volatile } \\
\text { extract }\end{array}$ & [40] \\
\hline & Liver, kidney in rat & Thyme extract & Protected cells against aflatoxin B1-induced toxicity & [43] \\
\hline & $\begin{array}{l}\text { Hamster lung V79 cells, human hepatoma } \\
\text { HepG2 cells }\end{array}$ & Thymol & $\begin{array}{l}\text { Showed free radical scavenging activity, reduced lipid peroxi- } \\
\text { dation and effected activity of enzymatic antioxidant defense } \\
\text { system }\end{array}$ & {$[45,46]$} \\
\hline & Acute promyelotic leukemia HL-60 cells & & $\begin{array}{l}\text { Induced cell cycle arrest in G0/G1 phase, pro-apoptotic signaling } \\
\text { pathway and apoptosis }\end{array}$ & {$[44]$} \\
\hline & Different human cell lines & Carvacrol & Defended oxidative DNA damage induced by $\mathrm{H}_{2} \mathrm{O}_{2}$ & {$[49,50]$} \\
\hline & Breast cancer cells & Thyme extract & $\begin{array}{l}\text { Caused cytotoxicity and apoptosis in cancer cells but not in } \\
\text { normal cells }\end{array}$ & [59] \\
\hline & Human hepatoma HepG2 cells & Carvacrol & $\begin{array}{l}\text { Induced apoptosis by activation of caspase- } 3 \text { and alterated } \\
\text { MAPK cell signalling }\end{array}$ & {$[60]$} \\
\hline \multirow[t]{6}{*}{ Rosemary } & $\begin{array}{l}\text { Human colon carcinoma Caco-2 cells, V79, } \\
\text { HepG2 cells }\end{array}$ & Rosemary extract & Showed DNA-protective effects against oxidative damage & {$[70,72,73]$} \\
\hline & Human hepatoma HepG2 cells & & $\begin{array}{l}\text { Modulated activity of antioxidant, detoxifying and repair } \\
\text { enzymes }\end{array}$ & {$[70,71]$} \\
\hline & Skin and liver cells (DMBA-treated mice) & & $\begin{array}{l}\text { Decreased lipid peroxidation, increased activity of SOD, CAT } \\
\text { and GPx }\end{array}$ & [69] \\
\hline & $\begin{array}{l}\text { Mouse macrophages/monocytes, colon cancer } \\
\text { HT- } 29 \text { cells }\end{array}$ & & $\begin{array}{l}\text { Reduced NO production, COX-2 expression and AP- } 1 \\
\text { activation }\end{array}$ & {$[77,78]$} \\
\hline & Neuronal HT22 cells & Carnosic acid & Induced cell cycle arrest and Nrf2 pathway activation & [81] \\
\hline & $\begin{array}{l}\text { Human hepatoma HepG2 cells, human } \\
\text { leukemia cells }\end{array}$ & Carnosol & $\begin{array}{l}\text { Caused G2/M cell cycle arrest and apoptosis through down- } \\
\text { regulation of Bcl-2 }\end{array}$ & {$[83,85]$} \\
\hline \multirow[t]{5}{*}{ Lavander } & - & Lavander extract & $\begin{array}{l}\text { Possessed less antioxidant activity than other members of } \\
\text { Lamiaceae family, scavanged ROS }\end{array}$ & {$[18,94]$} \\
\hline & - & & $\begin{array}{l}\text { Inhibited both enzyme-dependent and enzyme-independend } \\
\text { lipid peroxidation }\end{array}$ & [97] \\
\hline & & & Increased activity of SOD, CAT and GPx & [105] \\
\hline & Mouse macrophages/monocytes & Linalool & Decreased production of proinflammatory cytokines & [88] \\
\hline & Human leukemia cells & Linalool & $\begin{array}{l}\text { Induced activation of } \mathrm{p} 53 \text {, cyclin-dependent kinase inhibitors } \\
\text { and apoptosis without affecting growth of normal hematopoi- } \\
\text { etic cells }\end{array}$ & [110] \\
\hline
\end{tabular}

improvements in all tested parameters and histological pictures in the liver tissues.

Antispasmodic, antibacterial and anti-inflammatory activity of thymol has been reported by Deb et al. [22]. Previous investigations on thymol have indicated its cytoprotective activity against radiation-induced damage in in vitro and in vivo model systems.

Carvacrol and thymol showed antigenotoxic properties against known mutagens [23] and they also exhibited protective effects against $\mathrm{H}_{2} \mathrm{O}_{2}$-induced DNA damage in human colonic Caco-2, hepatoma HepG2 and leukemic K562 cell lines [24-25].

Rosmarinus officinalis. Rosmarinus officinalis L., commonly reffered as rosemary, is an evergreen branched and bushy shrub of Mediterranean origin and it has become a common household plant in many parts of the world. Rosemary is also used in medicine and cosmetics. In folk medicine it is used as an analgesic, anti-rheumatic, diuretic agent, expectorant and as hepatoprotectant [26]. Rosemary crude extract showed a number of in vitro and in vivo 


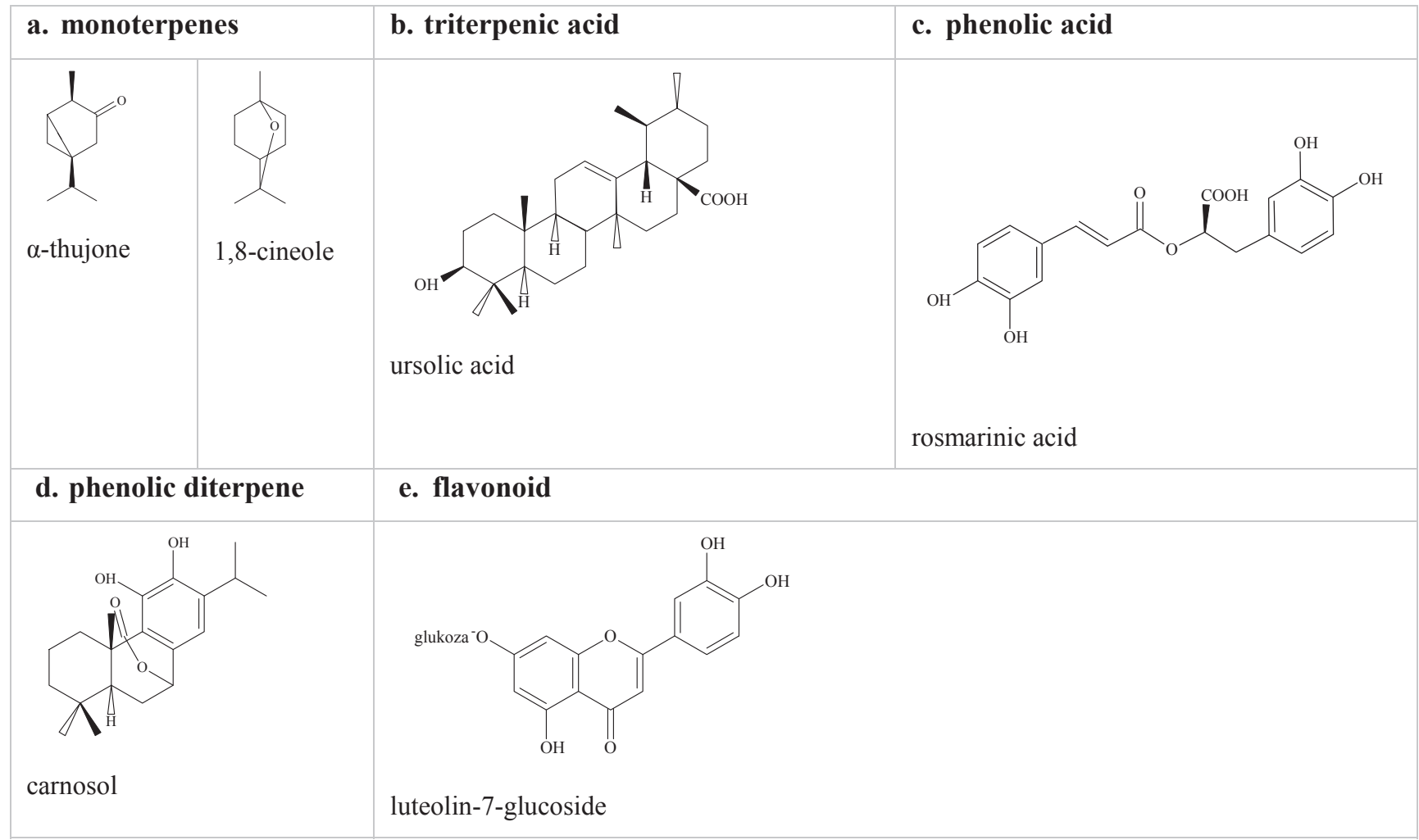

Figure 1. Chemical structures of main compounds in species from Lamiaceae.

biological activities including strong antioxidant power, antimutagenic effects [27], anti-inflammatory activities and in vitro anti-metastatic properties in B16/F10 mouse melanoma cells [28].

Some of the protective effects of rosemary extracts were attributed to enhancement of xenobiotic detoxification [29]. Two main compounds of rosemary, carnosol and carnosic acid inhibited mRNA expression and activity of cytochrome P450 (CYP1A) and increased glutathione S-transferase (GST) and quinon reductase mRNA expression and activities in human liver and bronchial cells $[30,31]$. Administration of rosemary extract to rats resulted in significantly higher activities of phase II enzymes: GST and $\mathrm{NAD}(\mathrm{P}) \mathrm{H}$ quinone reductase in their livers and the authors proposed that carnosol may have an important role in the antitumour activity of rosemary extracts [31].

It is interesting to note that constituents in rosemary have shown a variety of pharmacological activities including antiinflammatory properties. Cheung and Tai [32] provided that rosemary significantly reduced nitric oxide (NO) production by lipopolysaccharide (LPS)-activated cells in a dose-dependent manner. Moreover, rosemary extract supressed interleukin- $1 \beta$ and cyclooxygenase- 2 (COX-2) mRNA expression in these cells when compared to the untreated control. Scheckel et al. [33] proved that rosemary extract antagonizes activator protein-1-dependent activation of COX-2 expression in human cancer and nonmalignant cell lines. Based on literature data, carnosol, the phenolic diterpene found in rosemary, has potential to inhibit LPS-induced activation of two members of the mitogen-activated protein kinases, specifically extracellular signal-regulated kinase (ERK) and p38, and abrogated LPS-induced iNOS expression [34]. Study of Kontogianni et al. [35] indicated immunomodifying activity of rosemary extract attributed to the presence of betulinic acid and higher concentration of carnosic acid in comparision to S. officinalis. Moreover, both extracts exerted cytotoxic activity through dose-dependent impairment of viability and mitochondrial activity of rat insulinoma m5F (RINm5F) cells. Decrease of RINm5F viability was mediated by NO-induced apoptosis [35].

Lavandula angustifolia. Lavandula angustifolia (true lavander or English lavender) is a well-known aromatic plant rich in volatile oil which is frequently reported to contain linalool (20-50\% of the fraction) and linalyl acetate (25-46\% of the fraction) as the major oil constituents [36]. The plant was also reported to contain phenolics including flavonoids and the caffeic acid derivative of rosmarinic acid [37]. However, elaboration of our literature survey revealed that there is still a lack of detailed data on the polyphenolic contents as well as on the pharmacological activities of L. angustifolia. 
Majority of results concerning the effects of lavander in different model systems was obtained with lavander oil or with some of the major components of L. angustifolia. Lavander essential oil, volatile aromatic oily liquids isolated from Lavandula plants, possesses many therapeutic properties including antioxidant [38], anti-inflammatory [39], antimicrobial [38, 40], antiplatelet and antithrombotic [41], antimutagenic [42] and chemopreventive $[40,43]$ activities.

The study of Hudaib et al. [44] reported for the first time the xanthine oxidase (XO) inhibitory activities of L. angustifolia. Xantine oxidase serves as an important biological source of oxygen-derived free radicals that contribute to the oxidative damage of living tissues. The authors provided that lavander is a good source of effective crude inhibitors for $\mathrm{XO}$ which can be used in the treatment of gout and other XO-related disorders. An Eastern European study on rats reported that inhalation of the lavander essential oil may be able to restore normal activity of oxidative enzymes involved in normal metabolism [45].

A Japanese study reported that lavander oil inhibited the generation of singlet oxygen which causes the most damage in response to UVA/UVB radiation [46]. This suggests that the regular use of lavander oil in skin preparations could suppress the aging effects of sunlight on the skin. Wang et al. [47] found that treatment with lavander oil significantly decreased neurological deficit scores, infarct size, the levels of malondialdehyde, carbonyl and reactive oxygen species (ROS), and attenuated neuronal damage, upregulated antioxidant enzymes such as superoxide dismutase (SOD), glutathione peroxidase (GPx) and catalase (CAT) activities. These results suggested that the neuroprotective effects of lavander oil against cerebral ischemia/reperfusion injury in mice may be attributed to its antioxidant effects [47].

Until now, most studies indicated that anti-mutagenic properties may be due to inactivation of the mutagens by direct scavenging, antioxidant capture of radicals produced by a mutagen or activation of cell antioxidant enzymes [11]. Lavender oil also showed moderate antimutagenicity against Salmonella typhimurium TA98 strain exposed to the direct mutagen 1-nitropyrene [40]. Lavander main components, linalool and linalyl acetate, showed no mutagenic potential in Ames mutagenicity test, with or without metabolic activation [48], and linalool did not induce chromosomal aberrations when incubated with Chinese hamster ovary cells [49]. Besides, Huo et al. [39] investigated protective effects of linalool on inflammation in LPS-stimulated RAW 264.7 cells and in LPS-induced in vivo lung injury model. They demonstrated that linalool significantly decreased LPS-induced production of proinflammatory cytokines (tumor necrosis factor- $\alpha$ and interleukin-6) in vitro and in vivo. Furthermore, the activation of the nuclear factor-kappaB (NF-kB) and MAPK pathways was blocked by linalool in vitro.

Antioxidant effects of the compounds studied. Flavonoids and many other phenolic compounds of plant origin have been reported as ROS scavengers and are viewed as promising therapeutic drugs for free radical pathologies. Many plants belonging to Lamiaceae family show strong antoxidant activity and are considered to be useful agents for the prevention of different diseases.

Antioxidant activity of $S$. officinalis. Antioxidant activity of sage leaf extracts is largely attributable to various phenolic constituents including phenolic diterpenes such as carnosol [50] and hydroxycinnamic acid derivatives, notably rosmarinic acid [51]. In $\beta$-carotene bleaching test, the antioxidative activity of a dry acetone extract (15:1) from sage leaf was found to be $101-116 \%$ of that of the synthetic antioxidant butylated hydroxytoluene (BHT) [52]. Miliauskas et al. [37] described the relationship between phenolic content in sage and its ability to scavenge free radicals. Scavenging of intracellular ROS is one of the potential mechanisms contributing to the protective effects of many antioxidants [53].

Phospholipids of cellular membranes are extremely susceptible to oxidation due to their high content of polyunsaturated fatty acids, which participate in free radical chain reactions. Initial products, such as lipid hydroperoxides, afterwards produce reactive aldehydes and epoxides in the presence of metals [54]. The most prominent one is malondialdehyde, which is not only mutagenic and carcinogenic in mammals [55] but it can further react with DNA bases to form deleterious adducts. Protective effect of $S$. officinalis leaf on lipid peroxidation induced by some pro-oxidants was proved in rat brain and liver homogenates in vitro, and the effect of aqueous extract was attributed to the high reducing power and Fe(II) chelating ability which was accompanied with low hydroxyl radical scavenging ability [56]. Zupko et al. [57] reported that lipid peroxidation in both enzyme-dependent and enzymeindependent test systems were inhibited more effectively by sage leaf extract than by a-tocopheryl acid succinate (used as a positive control) and the antioxidant activity was attributed mainly to rosmarinic acid.

Oxidative DNA damage is present in relatively small amount in cells due to the balance between DNA damage and its repair. Plant extracts rich in phenolic compounds inhibited DNA breaks and 8-oxoguanine lesions induced by oxidative agents [58]. Ramos et al. [58] demonstrated chemopreventive effects of $S$. officinalis and $S$. fruticosa, and the isolated compounds (rosmarinic acid and luteolin-7-glucoside) by protecting cells against oxidative agents and stimulating DNA repair, (S. officinalis, S. fruticosa and luteolin-7-glucoside) in Caco- 2 and HeLa cells. These authors showed that sage extract tested and rosmarinic acid, its main constituent, protected human colon cell line CO115 from DNA damage induced by 1,3-bis-(2-chloroethyl)-1-nitosourea (BCNU). Sage water extracts and rosmarinic acid did not markedly change DNA repair protein expression in either cell line. Data showed that sage tea protected human colon cells against oxidative and alkylating DNA damage and may also interfere with efficacy of alkylating agents used in cancer therapy [59]. The study of Silva et al. [60] provided evidence that rosmarinic acid increased the repair of oxidized bases induced with the photosensitizer compound (Ro 19-8022) and had an effect on the expression 
of OGG1 repair gene in PC12 neuronal cells. Garrera et al. [61] showed that a flavonoid-rich diet increases expression of some DNA repair genes such as XRCC3 (involved in double strand breaks repair) in healthy male smokers.

Antioxidant activity of T. vulgaris. Thymol, the main constituent of thyme, was found to be also a main contributor to the antioxidant activity of thyme volatile extract at $10 \mu \mathrm{g} / \mathrm{ml}$, comparable to those of known antioxidants, BHT and $\alpha$-tocopherol at the same concentrations. Besides these, essential oil of thyme showed moderate inhibition of LDL oxidation and during autoxidation of lipids thymol was more effective in preventing oxidation than carvacrol [18].

Many studies provided evidence that monoterpenes thymol and carvacrol, the main components present in essential oil of thyme, possess antioxidant capacity. Thymol was found to inhibit various free radicals generated in vitro, including hydroxyl radicals, which would be considered as the primary reactive species responsible for the radiationinduced damage of bio-macromolecules, including DNA. In addition, thymol inhibited the radiation-induced decrease in intracellular glutathione, SOD and CAT enzyme levels in V79 cells accompanied by the reduction in lipid peroxides [62]. Same results indicated Phi et al. [63] who demonstrated protective effect of thymol against lipid peroxidation using HepG2 cells, radical-scavenging capacity as well as reducing power. Thus, Aeschbach et al. [64] reported that thymol and carvacrol possessed useful antioxidant properties, decreased peroxidation of phospholipid liposomes in the presence of $\mathrm{Fe}(\mathrm{III})$ and ascorbate, and were good scavengers of peroxyl radicals $\left(\mathrm{CCI}_{3} \mathrm{O}_{2}^{*}\right)$ but did not accelerate DNA damage in the bleomycin-Fe(III) system. Damage to DNA in the presence of a bleomycin-Fe complex has been accepted as one of the mechanism for examination of the potential pro-oxidant actions of lipid antioxidants.

Antioxidant activity of $\boldsymbol{R}$. officinalis. The most important chemical constituents of rosemary include flavonoids such as carnosol, carnosic and rosmarinic acids and volatile oils [65]. Carnosol and carnosic acid constitute $3.8-4.6 \%$ and $0.1-0.5 \%$, respectively [66]. Carnosic acid is not stable during processing and storage. It is first oxidized to carnosol which undergoes further oxidative transformation to form rosmanol [67]. Moreover, carnosic acid and carnosol are considered to account for more than $90 \%$ of the antioxidant properties of the rosemary extract; they are powerful inhibitors of lipid peroxidation and good scavengers of peroxyl radicals [68]. Studies on the chemical composition of $R$. officinalis confirmed also the presence of monoterpenes including $\alpha$ - and $\beta$-pinenes, together with 1,8 -cineole, borneol and camphor (20-50\% of the oil) [69, 70]. Zegura et al. [69] studied antioxidant and antigenotoxic effects of rosemary extract against mutagens 4-nitroquinoline$\mathrm{N}$-oxide and 2-amino-3-methyl-3H-imidazo[4,5-F] quinoline using Salmonella typhimurium. Additionaly, they provided evidence that $R$. officinalis protects HepG2 cells in pre- and co-treatment with tert-butyl hydroperoxide ( $t$-BHP). In cotreatment procedure, when HepG2 cells were simultaneously exposed to rosemary extract and $t$-BHP, extract may protect cells against oxidant-induced DNA damage directly either by free radical scavenging activity or by decreasing free radical production through iron chelation [71]. On the other hand, in the case of pre-treatment, extract may indirectly act as antioxidant in cells by modulating the activity of antioxidant, detoxifying and repair enzymes as well as enzymes involved in the bioactivation of xenobiotics [72]. This is in agreement with findings of Slamenova et al. [73] who described that pre-treatment of human colon cancer (Caco-2) and hamster lung (V79) cells with rosemary extract reduced the level of DNA strand breaks and oxidative DNA damage induced by $\mathrm{H}_{2} \mathrm{O}_{2}$ and visible light-excited methylene blue. Recently, Horvathova et al. [74] showed that in hepatocytes isolated from rats supplemented with rosemary oil, decreased level of DNA damage induced by oxidative stress was detected in comparison to control rats.

Antioxidant activity of $\boldsymbol{L}$. angustifolia. Lavander oil has shown a modest antioxidant activity in several assays [75]. Its antioxidant activity is less potent than in other members of the Labiatae family. In the study by Dapkevicius et al. [52], none of six different types of extracts from L. angustifolia exhibited any antioxidant activity in a $\beta$-carotene bleaching test. Other studies reported that lavender does exhibit antioxidant properties. In the study by Billany et al. [76] lavander oil and two of its chemical constituents, cineole and $\beta$-pinene, slowed the normal rate of a hydroxyl radical mediated chemical reaction more than either ethanol and mannitol, known hydroxyl radical scavengers. The essential oil of L. angustifolia mildly slowed auto-oxidation in lard [77]. Similarly, a phenolic compound from $L$. angustifolia prevented the development of oxidative rancidity in vegetable oils in a dose dependent manner comparable to $200 \mathrm{ppm}$ butylated hydroxyanisole (BHA) and BHT [78]. Extracts of L. angustifolia exerted a concentration-dependent inhibition against both enzymedependent and enzyme-independent lipid peroxidation [79]. Blazekovic et al. [80] obtained correlation coefficients which exhibited a strong positive association among different modes of antioxidant action (antiradical activity, reducing power and inhibition of lipid peroxidation) and contents of phenolic acids and total polyphenols in lavander extracts, indicating that phenolic compounds could be the major contributors to their antioxidant properties.

Chemopreventive effects of the compounds studied. A large number of medicinal herbs were reported to have chemopreventive properties. It is important to note that chemopreventive agents may act by a different ways, as chemical inactivators, antimutagens, enzymatic inducers, antioxidans and tumor growth suppressors [81]. The can influence one of several steps of carcinogenesis (Figure 2). Many of nutritional substances might influence carcinogenesis through more than one mechanism. The most useful cancer chemoprotective agents should have significant ability to reduce tumor incidence, delay tumor onset and prevent tumor progression. 


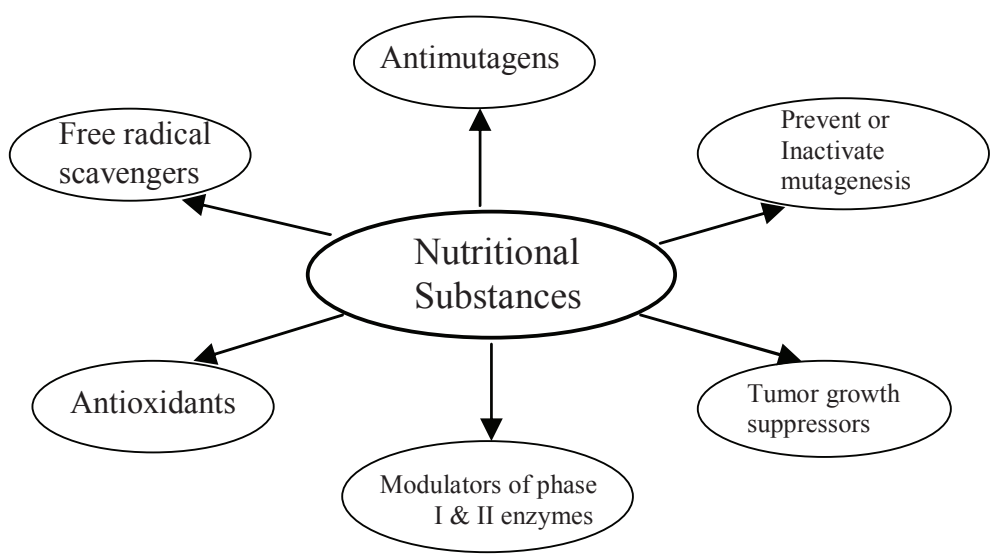

Figure 2. Possible roles of nutritional substances against carcinogenesis (taken from Manoharan et al. [81]).

Chemopreventive effects of S. officinalis. Inhibition of cell proliferation and induction of apoptosis represent the two strategies of chemopreventive agents to block tumor promotion. Aromatic plants of the genus Salvia (sage) except antioxidant activity have also been suggested to have anticancer properties based on antiproliferative activity on tumor cells [82]. In addition, ROS have been reported to play a role in signalling transduction enhancing proliferation and survival of cancer cells. Antioxidant phytochemicals, through their ROS scavenging activity, may suppress altered redox-sensitive signalling events in cancer. Xavier et al. [9] investigated the antiproliferative and proapoptotic effects of S. officinalis, S. fruticosa and rosmarinic acid on human colon carcinoma cell lines, HCT15 and CO115, which have different mutations in MAPK/ERK and phosphatidylinositol 3-kinase (PI3K/Akt) signalling pathways. Interestingly, they found that SF, SO and rosmarinic acid induce apoptosis in both cell lines, whereas cell proliferation was inhibited by the two sage extracts only in HCT15. SO, SF and rosmarinic acid inhibited ERK phosphorylation in HCT15 and had no effects on Akt phosphorylation in CO115 cells. The activity of sage extracts seems to be due, at least in part, to the inhibition of MAPK/ERK pathway. Moreover, the sage components linalyl acetate (Ly) and $\alpha$-terpineol (Te) exhibited synergistic antiproliferative effects. Deeb et al. [83] investigated the effect of Ly and Te on NFkB signaling in HCT-116 colon cancer cells. The combination of these components reduced dosedependently cell viability at non-cytotoxic concentrations, increased cells at PreG1 phase and suppressed NFkB activation. Authors refered that NFkB suppression correlated with the inhibition of $\mathrm{p} 65$ nuclear translocation and IkappaB-alpha degradation. Furthermore, separate treatments and drug combinations significantly decreased DNA binding activity of NFkB which led to the potentiation of cell death induced by the colon cancer drugs oxaliplatin and 5-fluorouracil. These study demonstrated possible use of Ly and Te in combination with chemotherapeutic agents to induce apoptosis and their anticancer effects are partly mediated through the suppression of NFKB [83].

As mentioned before, sage is also known to affect signaling pathaways. Sertel et al. [84] found that the three most significantly regulated pathways by sage were aryl hydrocarbon receptor signaling, cell cycle (G1/S checkpoint) regulation, and p53 signaling in cavity squamous human cell carcinoma cell line (UMSCC1).

Bauer et al. [85] demonstrated that carnosol and carnosic acid from S. officinalis suppressed the formation of prostaglandin $\mathrm{E} 2\left(\mathrm{PGE}_{2}\right)$, the most relevant eicosanoid promoting inflammation and tumorigenesis. During biosynthesis of $\mathrm{PGE}_{2}$, arachidonic acid is transformed to prostaglandin $\mathrm{H}_{2}$ $\left(\mathrm{PGH}_{2}\right)$ by cyclooxygenases and further converted to PGE2 by PGE2 synthases [86]. Carnosol and carnosic acid inhibited PGE2 formation by selectively targeting microsomal PGE(2) synthase (mPGES)-1, isoenzyme functionally coupled with COX-2. Both of these enzymes are induced by pro-inflammatory stimuli and overexpressed in tumors [85].

Over the last years, more attention is focused on the antiangiogenic and anti-tumor effects of non toxic compounds present in commonly used herbs. Ethanol extract of $S$. officinalis exhibited a significant inhibitory activity on the endothelial cells migration as well as on the proliferation of different blood cells, but cell proliferation was supressed only at higher concentration. These findings indicated that anti-angiogenic effect of sage extract might be due to anti-migratory activity [87] attributed to anti-proteases and/or interference of cytoskeleton organization which is known to play important roles in cell locomotion and capillary tube formation [88].

In an attempt to explain the cytoprotective activities, the effects of sage extracts and phenolic compounds on three markers of cellular oxidative stress (lipid peroxidation, glutathione [GSH] level and DNA damage) were evaluated. Both sage extract and phenolic compounds (rosmarinic acid and luteolin-7-glucoside) significantly prevented lipid peroxidation and GSH depletion but failed to prevent DNA damage induced 
by $t$-BHP [89]. GSH plays an important role in hepatocyte defence against ROS, free radicals and electrophilic metabolites and its depletion may lead to alterations in cellular calcium homeostasis and subsequently to cell death [90]. Since the increase in GSH level was accompanied by an increase in total glutathione level (and not to a reduction in oxidized glutatione [GSSG] level), sage extracts seem to have an ability to increase de novo synthesis of glutathione [89].

DNA damage induced by oxidative and alkylating agents contributes to carcinogenesis, leading to possible mutations if replication proceeds without proper repair. However, some alkylating agents are used in cancer therapy due to their ability to induce DNA damage and subsequently apoptosis of tumor cells. Ramos et al. [27] found protective effect of $S$. officinalis extract against oxidative $\left(\mathrm{H}_{2} \mathrm{O}_{2}\right)$ DNA damage in human colon HCT15 cells and decreased DNA damage induced by $\mathrm{N}$-methyl-N-nitrosourea in CO115 human colon cell line. In addition to chemopreventive effects of sage extracts, it was also important to know whether these plant extracts may interfere with alkylating agents such as nitrosourea used in cancer therapy, decreasing their efficacy.

Chemopreventive activity of T. vulgaris. Bozkurt et al. [91] reported that methanolic extract of T. serpyllum (wilde thyme) induced significant cytotoxicity and apoptosis in breast cancer cells but not in normal cells. It is notable that the extracts from thyme exhibited the strongest antioxidant capacity followed by sage and marjoram. As observed, extracts with higher antioxidant capacity had also higher polyphenol contents. Additionally, carvacrol inhibited 7,12dimethylbenz(a)anthracene (DMBA) induced tumorigenesis in rats [92], growth of murine B16 melanomas [93] and human non-small lung cancer A549 cell line [94], while thymol significantly increased activities of antioxidant enzymes such as SOD and GPx in rats [95].

Induction of apoptosis and influence on the cell cycle as well as suppression of angiogenesis are playing roles in chemopreventive potential of many natural compounds. Apoptosis is an active form of cell suicide, leads to cell shrinkage, chromatin condensation, membrane blebbing and DNA degradation [96]. It is noteworthy that mitochondria play a vital role in induction of apoptosis through release of proteins that propagate both caspase-dependent and caspase-independent pathways. Deb et al. [22] reported on the anticancer activity of thymol on acute promyelotic leukemia HL-60 cells but did not show any cytotoxic effect in peripheral blood mononuclear cells. The cytotoxic effect of thymol on HL-60 cells appears to be associated with induction of cell cycle arrest at sub G0/G1 phase which is irreversible and leads the cell to undergo apoptosis. Thymol also showed significant increase in production of ROS activity, increase in mitochondrial $\mathrm{H}_{2} \mathrm{O}_{2}$ production and depolarization of mitochondrial membrane potential. Some other important players in apoptosis were affected, there was observed increase in pro-apoptotic protein Bax level with a concomitant decrease in $\mathrm{Bcl} 2$ protein expression, one of the anti-apoptotic protein overexpressed in a wide variety of cancers [97].
Literatures have shown that loss of mitochondrial membrane potential leads to activation of caspases, which plays an important role in the execution phase of apoptosis. Initiator caspase, such as caspase- 8 and caspase-9, either directly or indirectly activates effector caspases, such as caspase-3 [98]. Treatment of cells with thymol resulted in activation of initiator caspase- 8 and -9 , effector caspase- 3 and then intracellular substrate, poly(ADP-ribose)polymerase (PARP) cleavage, resulting in apoptosis. Moreover, thymol was also able to induce caspase-independent apoptosis [22]. Research of Ferraz et al. [99] showed cytotoxicity of Lippia gracilis EO treatment on HepG2 cells. Lippia gracilis is a medicinal plant, which has thymol as its major constituent. In this study EOtreatment caused G1 arrest accompanied by the induction of DNA fragmentation without affecting cell membrane integrity. Cell morphology consistent with apoptosis and a remarkable activation of caspase- 3 were also observed, suggesting induction of caspase-dependent apoptotic cell death. Carvacrol, one of the members of monoterpene phenols present in the volatile oils of T. vulgaris, inhibited viability and proliferation of A549 cells, a human non-small cell lung cancer, and induced early apoptotic features in a dose-dependent manner [94]. In the study conducted by Yin et al. [100], carvacrol affected apoptosis of human hepatoma HepG2 cells by the activation of caspase-3, cleavage of PARP and decreased Bcl2 gene expression. Moreover, carvacrol selectively altered the phosphorylation state of members of the MAPK superfamily, decreasing phosphorylation of ERK significantly in a dosedependent manner, and activated phosphorylation of p 38 but not affecting JNK MAPK phosphorylation.

In animal model, Ferraz et al. [99] confirmed that $\mathrm{EO}$ of Lippia gracilis possesses antitumor activity. Mice were subcutaneously transplanted with sarcoma 180 cells and treated by intraperitoneal route with EO for 7 days and they showed tumor growth inhibition rates of $38.5-41.9 \%$.

Chemopreventive activity of $R$. officinalis. Recent studies described pharmacological effects of rosemary in chemoprevention as well as in cancer therapy. In order to explore the chemopreventive properties of rosemary extract, Parmar et al. [70] focused their research on the antitumor-promoting activity of $R$. officinalis on skin carcinogenesis induced by DMBA in mice. After administration of rosemary extract to mice significant decrease in lipid peroxidation, GSH and total protein levels in their skin and livers was observed. Skin and livers of R. officinalis treated animals showed significant enhancement in activities of antioxidant enzymes such as SOD and CAT. This findings indicated that $R$. officinalis could reduce chemically induced tumors. Carnosol, the oxidized form of carnosic acid, also induced G2/M cell cycle arrest through altering the levels of cyclin A and cyclin B1 [101], inhibited invasion in B16/F10 melanoma cells, possibly through inhibition of NFkB signaling pathway. Constitutively active NFKB has now been identified in tissues of most cancer patients, including prostate, breast, oral, pancreas and colon cancer [102]. Carnosol limited the translocation of NFkB subunits to the nucleus and reduced NFKB DNA binding activity in activated 
macrophages due to the inhibitor of kappa B inactivation [34]. Both carnosol and rosemary extract increased apoptosis through down-regulating Bcl-2 in human leukemia [103] and human ovarian cancer cells in vitro [104], respectively.

Chemopreventive activity of $\boldsymbol{L}$. angustifolia. It has been reported that linalool exhibits antiproliferative activity against certain solid tumor cells, such as melanoma, renal adenocarcinoma [105] and HepG2 cells [106]. Particularly, linalool induced apoptosis in human leukemia cells without affecting growth of normal hematopoietic cells [107] and it was an effective doxorubicin modulator [108].

Perillyl alcohol (POH) was found in lavender, as well [109]. It blocks cell division, induces apoptosis and, in some cases, induces differentiation. In rats who received a diet supplemented with POH for 52 weeks, the total incidence of adenocarcinomas in the colon was significantly reduced, and the tumors that did occur exhibited a significantly higher apoptotic index compared to the tumors examined from unsupplemented animals [110]. In a randomized trial in mice, those given $\mathrm{POH}$ injections prior to administration of a lung carcinogen and three times a week for 22 weeks afterward showed a $22 \%$ reduction in tumor incidence and a 58\% reduction in tumor multiplicity [109]. Perillyl alcohol is in Phase I clinical trials for use as a chemoprotective and chemotherapeutic agent against advanced breast, ovarian and prostate cancers [111]. Linalool, one of the major constituents of lavander oil, has shown very good in vitro activity against human basal cell carcinoma [112] and a topically applied $10 \%$ dilution of linalool reduced skin tumor incidence in mice by $33 \%$ [113].

\section{Conclusion}

Lamiaceae family species are considered important because of their use in folk medicine and in culinary and flavouring remedies throughout the world. Their interesting bioactivities are attributed mainly to essential oils, polyphenols and terpenes. Numerous studies have demonstrated that plant extracts exhibit many useful technological and biological properties, e.g. it is well known that plant extracts have potent antioxidant power and more recent studies showed their anticarcinogenic and anti-inflammatory activities. Based on these findings plant extracts and their components represent promising candidates for their use in pharmacological industry or a fertile ground for the development of novel anticancer drugs structurally derived from natural compounds which, of course, require further extensive scientific and clinical investigations.

Acknowledgements: The authors thank to Dr. D. Slamenova for critical reading of the manuscript and for valuable advices and comments.

This study is the result of the contributions from the Scientific Grant Agency of the Ministry of Education of Slovak Republic and the Academy of Sciences (VEGA) Grants 2/0012/12, 2/0177/11, the project implementations: TRANSMED, ITMS: 26240120008 and TRANSMED 2, ITMS: 26240120030 supported by the Research \& Development Operational Programme funded by the ERDF.

\section{References}

[1] PAN MH, HO CT Chemopreventive effects of natural dietary compounds on cancer development. Chem Soc Rev 2008; 37: 2558-2574. http: //dx.doi.org/10.1039/b801558a

[2] GUPTA SC, KIM JH, PRASAD S, AGGARWAL BB. Regulation of survival, proliferation, invasion, angiogenesis, and metastasis of tumor cells through modulation of inflammatory pathways by nutraceuticals. Cancer Metastasis Rev. 2010; 29: 405-434. http: //dx.doi.org/10.1007/s10555-010-9235-2

[3] HANAHAN D, WEINBERG RA The hallmarks of cancer. Cell 2000; 100: 57-70. http: //dx.doi.org/10.1016/S00928674(00)81683-9

[4] HAZRA B, DAS SM, KUMAR B, BASU S, DAS K et al. Cytotoxicity of diospyrin and its derivatives in relation to the generation of reactive oxygen species in tumor cells in vitro and in vivo. Chemotherapy 2007; 53: 173-176.

[5] ANAND P, SUNDARAM C, JHURANI S, KUNNUMAKKARA AB, AGGARWAL, BB Curcumin and cancer: An "old-age" disease with an "age-old" solution. Cancer Letters 2008; 267: 133-164. http: //dx.doi.org/10.1016/j.canlet.2008.03.025

[6] LONGARAY-DELAMARE AP, MOSCHEN-PISTORELLO IT, ARTICO L, ATTI-SERAFINI L, ECHEVERRIGARAY $S$ Antibacterial activity of the essential oils of Salvia officinalis L. and Salvia triloba L. cultivated in South Brazil. Food Chem 2007; 100: 603-608. http: //dx.doi.org/10.1016/ j.foodchem.2005.09.078

[7] BEN FARHAT M, JORDAN M J, CHAOUECH-HAMADA R, LANDOULSI A,SOTOMAYOR J A Variations in essential oil, phenolic compounds, and antioxidant activity of Tunisian cultivated Salvia officinalis L. J. Agric. Food Chem. 2009; 57: 10349-10356. http: //dx.doi.org/10.1021/jf901877x

[8] LIMA CF, ANDRADE PB, SEABRA RM, FERNANDES-FERREIRA M, PEREIRA-WILSON C The drinking of a Salvia officinalis infusion improves liver antioxidant status in mice and rats. J Ethnopharmacol 2005; 97: 383-389. http: //dx.doi. org/10.1016/j.jep.2004.11.029

[9] XAVIER CP, LIMA CF, FERNANDES-FERREIRA M, PEREIRA-WILSON C Salvia fruticosa, Salvia officinalis, and rosmarinic acid induce apoptosis and inhibit proliferation of human colorectal cell lines: the role in MAPK/ERK pathway. Nutr Cancer 2009; 61: 564-571. http: //dx.doi.org/10.1080/ $\underline{01635580802710733}$

[10] HADRI A, RIO MAG, SANZ J, COLOMA AG, IDAOMAR M et al. Cytotoxic activity of $\alpha$-humulene and transcaryophyllene from Salvia officinalis in animal and human tumor cells. An. R. Acad. Nac. Farm. 201076 : 343-356.

[11] BAKKALI F, AVERBECK S, AVERBECK D, IDAOMAR M. Biological effects of essential oils - A review. Food Chem. Toxicol 2008; 46: 446-475. http: //dx.doi.org/10.1016/ j.fct.2007.09.106

[12] TOPCU G Bioactive triterpenoids from Salvia species. J Nat Prod 2006; 69: 482-487. http: //dx.doi.org/10.1021/ $\underline{\text { np0600402 }}$

[13] BARICEVIC D, BARTOL T The biological/pharmacological activity of the Salvia genus. Harw Acad Pub Amsterdam 2000; 143-184. 
[14] SHAN B, CAI YZ, SUN M, CORKE H Antioxidant capacity of 26 spice extracts and characterization of their phenolic constituents. J Agric Food Chem 2005; 53: 7749-7759. http: //dx.doi.org/10.1021/if051513y

[15] ZIMMERMANN BF, WALCH SG, TINZOH LN, STÜHLINGER W, LACHENMEIER DW Rapid UHPLC determination of polyphenols in aqueous infusions of Salvia officinalis L. (sage tea). J Chromatogr B Analyt Technol Biomed Life Sci 2012; 879: 2459-64. http: //dx.doi.org/10.1016/ j.jchromb.2011.06.038

[16] WHO (Eds.) WHO Monographs on Selected Medicinal Plants. vol. 1 Geneva: 1999.

[17] RUSTAIYAN A, MASOUDI S, MONFARED A, KAMALINEJAD M, LAJEVARDI S, et al. Volatile constituents of three Thymus species grown wild in Iran. Planta Med. 2000; 66: 197. http: //dx.doi.org/10.1055/s-0029-1243136

[18] LEE SJ, UMANO K, SHIBAMOTO T, LEE K Identification of volatile components in basil (Ocimum basilicum L.) and thyme leaves (Thymus vulgaris L.) and their antioxidant properties. Food Chem 2005; 91: 131-137. http: //dx.doi. org/10.1016/j.foodchem.2004.05.056

[19] OZCAN M, CHALCHAT JC Aroma profile of Thymus vulgaris L. growing wild in Turkey. J Plant Physiol 2004; 30: 68-73.

[20] ROBY MHH, SARHANA MH, SELIMA KA, KHALELA KI Evaluation of antioxidant activity, total phenols and phenolic compounds in thyme (Thymus vulgaris L.), sage (Salvia officinalis L.), and marjoram (Origanum majorana L.) extracts. Ind Crops Prod 2013; 43: 827-831. http://dx.doi.org/10.1016/ j.indcrop.2012.08.029

[21] EL-NEKEETY AA, MOHAMED SR, HATHOUT AS, HASSAN NS, ALY SE, et al. Antioxidant properties of Thymus vulgaris oil against aflatoxin-induce oxidative stress in male rats. Toxicon 2011; 57: 984-91. http: //dx.doi.org/10.1016/ j.toxicon.2011.03.021

[22] DEB DD, PARIMALA G, DEVI SS, CHAKRABORTY T Effect of thymol on peripheral blood mononuclear cell PBMC and acute promyelotic cancer cell line HL-60. Chem Biol Interac 2011; 193: 97-106. http: //dx.doi.org/10.1016/ j.cbi.2011.05.009

[23] VICUNA GC, STASHENKO EE, FUENTES JL Chemical composition of the Lippia origanoides essential oils and their antigenotoxicity against bleomycin-induced DNA damage. Fitoterapia 2010; 81: 343-349. http: //dx.doi.org/10.1016/ j.fitote.2009.10.008

[24] HORVATHOVA E, TURCANIOVA V, SLAMENOVA D Comparative study of DNA-damaging and DNA-protective effects of selected components of essential plant oils in human leukemic cells K562. Neoplasma 2007; 54: 478-483.

[25] SLAMENOVA D, HORVATHOVA E, SRAMKOVA M, MARSALKOVA L DNA-protective effects of two components of essential plant oils carvacrol and thymol on mammalian cells cultured in vitro. Neoplasma 2007; 54: 108-112.

[26] BOWN D Encyclopedia of herbs and their uses. New York: DK Publishing, Inc. 1995.

[27] MINNUNNI M, WOLLEB U, MUELLER O, PFEIFER A, AESCHBACHER HU Natural antioxidants as inhibitors of oxygen species induced mutagenicity. Mutat Res Fundam
Mol Mech Mutagen 1992; 269: 193-200. http: //dx.doi. org/10.1016/0027-5107(92)90200-L

[28] HUANG SC, HO CT, LIN-SHIAU SY, LIN JK Carnosol inhibits the invasion of B16/F10 mouse melanoma cells by suppressing metalloproteinase-9 through down-regulating nuclear factor-kappaB and c-Jun. Biochem Pharmacol 2005; 69: 221-232. http: //dx.doi.org/10.1016/j.bcp.2004.09.019

[29] SINGLETARY KW, ROKUSEK JT Tissue-specific enhancement of xenobiotic detoxification enzymes in mice by dietary rosemary extract. Plant Foods Hum Nutr 1997; 50: 47-53. http: //dx.doi.org/10.1007/BF02436042

[30] OFFORD EA, MACE K, AVANTI O, PFEIFER AMA Mechanisms involved in the chemoprotective effects of rosemary extract studied in human liver and bronchial cells. Cancer Lett 1997; 114: 275-281. http: //dx.doi.org/10.1016/S03043835(97)04680-6

[31] SINGLETARY K, MACDONALD C, WALLIG M Inhibition by rosemary and carnosol of 7,12-dimethylbenz[a]anthracene (DMBA)-induced rat mammary tumorigenesis and in vivo DMBA-DNA adduct formation. Cancer Lett 1996; 104: 43-48. http: //dx.doi.org/10.1016/0304-3835(96)04227-9

[32] CHEUNG S, TAI J Anti-proliferative and antioxidant properties of rosemary Rosmarinus officinalis. Oncol. Rep 2007; 17: 1525-31.

[33] SCHECKEL KA, DEGNER SC, ROMAGNOLO DF Rosmarinic acid antagonizes activator protein-1-dependent activation of cyclooxygenase- 2 expression in human cancer and nonmalignant cell lines. J Nutrition 2012; 138: 2098-2105. http: //dx.doi.org/10.3945/jn.108.090431

[34] LO AH, LIANG YC, LIN-SHIAU SY, HO CT, LIN JK Carnosol, an antioxidant in rosemary, suppresses inducible nitric oxide synthase through down-regulating nuclear factor-kappaB in mouse macrophages. Carcinogenesis 2002; 23: 983-91. http: //dx.doi.org/10.1093/carcin/23.6.983

[35] KONTOGIANNI VG, TOMIC G, NIKOLIC I, NERANTZAKI AA, SAYYAD $\mathrm{N}$ et al. Phytochemical profile of Rosmarinus officinalis and Salvia officinalis extracts and correlation to their antioxidant and anti-proliferative activity. Food Chem 2013; 136: 120-129. http: //dx.doi.org/10.1016/ j.foodchem.2012.07.091

[36] EUROPEAN MEDICINES AGENCY Assessment report on Lavandula angustifolia Mill., aetheroleum and Lavandula angustifolia Mill., flos. EMA/HMPC 2011; 143183/2010.

[37] MILIAUSKAS G, VENSKUTONIS PR, BEEK TA Screening of radical scavenging activity of some medicinal and aromatic plant extracts. Food Chem 2004; 85: 231-237. http: //dx.doi. org/10.1016/j.foodchem.2003.05.007

[38] DANH LT, HAN LN, TRIET NDA, ZHAO J, MAMMUCARI $\mathrm{R}$ et al. Comparison of chemical composition, antioxidant and antimicrobial activity of lavender (Lavandula angustifolia L.) essential oils extracted by supercritical CO2, hexane and hydrodistillation. Food Bioprocess Technol 2012; 1935-5130.

[39] HUO M, CUI X, XUE J, CHI G, GAO R et al. Anti-inflammatory effects of linalool in RAW 264.7 macrophages and lipopolysaccharide-induced lung injury model. J Surg Res 2013; 180: 47-54. http: //dx.doi.org/10.1016/j.jss.2012.10.050 
[40] LAI PK, ROY J Antimicrobial and chemopreventive properties of herbs and spices. Curr Med Chem 2004; 11: 1451-1460. http: //dx.doi.org/10.2174/0929867043365107

[41] BALLABENI V, TOGNOLINI M, CHIAVARINI M, IMPICCIATORE M, BRUNI R et al. Novel antiplatelet and antithrombotic activities of essential oil from Lavandula hybrida reverchon „grosso“. Phytomedicine 2004; 11: 596-601. http: //dx.doi.org/10.1016/j.phymed.2004.01.002

[42] EVANDRI MG, BATTINELLI L, DANIELE C, MASTRANGELO S, BOLLE $P$, et al. The antimutagenic activity of Lavandula angustifolia (lavender) essential oil in the bacterial reverse mutation assay. Food Chem. Toxicol 2005; 43: 1381-1387. http: //dx.doi.org/10.1016/j.fct.2005.03.013

[43] SHEN J, NIIJIMA A, TANIDA M, HORII Y, NAKAMURA $\mathrm{T}$ et al. Mechanism of changes induced in plasma glycerol by scent stimulation with grapefruit and lavender essential oils. Neurosci Lett 2007; 416: 241-246. http://dx.doi.org/10.1016/ j.neulet.2006.12.063

[44] HUDAIB MM, TAWAHA KA, MOHAMMAD MK, ASSAF AM, ISSA AY et al. Xanthine oxidase inhibitory activity of the methanolic extracts of selected Jordanian medicinal plants. Pharm. Magazine 2011; 7: 320-324. http: //dx.doi. org/10.4103/0973-1296.90413

[45] YURKOVA O Vegetable aromatic substances influence on oxidative-restoration enzymes state in chronic experiment with animals. Fiziol Zh 1999; 45: 40-43.

[46] SAKURAI H, YASUI H, YAMADA Y, NISHIMURA H, SHIGEMOTO M Detection of reactive oxygen species in the skin of live mice and rats exposed to UVA light: a research review on chemiluminescence and trials for UVA protection. Photochem \& Photobiol Scie 2005; 4: 715-720. http: //dx.doi. org/10.1039/b417319h

[47] WANG D, YUAN X, LIU T, LIU L, HU Y et al. Neuroprotective activity of lavender oil on transient focal cerebral ischemia in mice. Molecules 2012; 17: 9803-9817. http: //dx.doi. org/10.3390/molecules 17089803

[48] ISHIDATE M, SOFUNI T, YOSHIKAWA K, HAYASHI M, NOHM IT et al. Primary mutagenicity screening of food additives currently used in Japan. Food Chem Toxicol 1984; 22: 623-636. http: //dx.doi.org/10.1016/0278-6915(84)90271$\underline{0}$

[49] BICKERS D, CALOW P, GREIM H, HANIFIN JM, ROGERS AE et al. A toxicological and dermatological assessment of linalool and related esters when used as fragrance ingredients. Food Chem Toxicol 2003; 41: 919-942. http: //dx.doi. org/10.1016/S0278-6915(03)00016-4

[50] WANG M, LI J, RANGARAJAN M, SHAO Y, LAVOIE EJ et al. Antioxidative phenolic compounds from sage (Salvia officinalis). J Agric Food Chem 1998; 46: 4869-4873. http: //dx.doi.org/10.1021/jf980614b

[51] LAMAISON JL, PETITJEAN-FREYTET C, DUBAND F, CARNAT AP Rosmarinic acid content and antioxidant activity in French Lamiaceae. Fitoterapia 1991; 62: 166-171.

[52] DAPKEVICIUS A, VENSKUTONIS R, VAN BEEK TA, LINSSEN JPH Antioxidant activity of extracts obtained by different isolation procedures from some aromatic herbs grown in Lithuania. J Sci Food Agric 1998; 77: 140-146. http:
//dx.doi.org/10.1002/(SICI)1097-0010(199805)77: 1<140: : AID-JSFA $18>3.0 . \mathrm{CO} ; 2-\mathrm{K}$

[53] CHEN X, ZHONG Z, XU Z, CHEN L, WANG Y. No protective effect of curcumin on hydrogen peroxide-induced cytotoxicity in HepG2 cells. Pharmacol Rep 2011; 63: 724-32.

[54] VALKO M, IZAKOVIC M, MAZUR M, RHODES CJ, TELSER J Role of oxygen radicals in DNA damage and cancer incidence. Mol Cell Biochem 2004, 266, 37-56. http: //dx.doi. org/10.1023/B: MCBI.0000049134.69131.89

[55] BASU AK, MARNETT LJ Unequivocal demonstration that malondialdehyde is a mutagen. Carcinog 1983; 4: 331-333. http: //dx.doi.org/10.1093/carcin/4.3.331

[56] OBOH G, HENLE T Antioxidant and inhibitory effects of aqueous extracts of Salvia officinalis leaves on pro-oxidant induced lipid peroxidation in brain and liver in vitro. J Med Food 2009; 12: 77-84. http: //dx.doi.org/10.1089/ jmf.2008.0007

[57] ZUPKO I, HOHMANN J, REDEI D, FALKAY G, JANICSAK $\mathrm{G}$ et al. Antioxidant activity of leaves of Salvia species in enzyme-dependent and enzyme-independent systems of lipid peroxidation and their phenolic constituents. Plant Medic 2001; 67: 366-368. http: //dx.doi.org/10.1055/s-2001$\underline{14327}$

[58] RAMOS AA, AZQUETA A, PEREIRA-WILSON C, COLLINS AR Polyphenolic compounds from Salvia species protect cellular DNA from oxidation and stimulate DNA repair in cultured human cells. J Agric Food Chem 2010; 58: 7465-7471. http: //dx.doi.org/10.1021/jf100082p

[59] RAMOS AA, PEDRO D, COLLINS AR, PEREIRA-WILSON C Protection by Salvia extracts against oxidative and alkylation damage to DNA in human HCT15 and CO115 cells. J Toxicol Environ Health A 2012; 75: 765-75. http: //dx.doi. org/10.1080/15287394.2012.689804

[60] SILVA JP, GOMES AC, COUTINHO OP Oxidative DNA damage protection and repair by polyphenolic compounds in PC12 cells. Eur J Pharmacol 2008; 601: 50-60. http: //dx.doi. org/10.1016/j.ejphar.2008.10.046

[61] GARRERA S, SACERDOTE C, FIORINI L, MARSALA R, POLIDORO S, et al. Expression of DNA repair and metabolic genes in response to a flavonoid-rich diet. Br J Nutr 2007; 98: 525-533. http: //dx.doi.org/10.1017/S0007114507725151

[62] ARCHANA PR, NAGESHWAR RHAO B, SATISH RAO BS In vivo radioprotective potential of thymol, a monoterpene phenol derivative of cymene. Mut Res 2011; 726: 136-145. http: //dx.doi.org/10.1016/j.mrgentox.2011.08.007

[63] PHI KC, KIM GN, JANG HD In vitro and intracellular antioxidant capacity of thymyl methyl ether as a major component in Blumea lanceolaria (Roxb.) Druce leaf oil. Food Chem Toxicol 2012; 50: 1583-1588. http: //dx.doi.org/10.1016/ j.fct.2012.01.047

[64] AESCHBACH R, LOLIGER J, SCOTT BC, MURCIA A, BUTLER J et al. Antioxidant actions of thymol, carvacrol, 6-gingerol, zingerone and hydroxytyrosol. Food Chem Toxicol 1994; 32: 31-36. http: //dx.doi.org/10.1016/02786915(84)90033-4

[65] OKAMURA N, HARAGUCHI H, HASHimOTO K, YAGI A Flavonoids in Rosmarinus officinalis leaves. 
Phytochemistry 1994; 37: 1463-1466. http: //dx.doi.org/ 10.1016/S0031-9422(00)90434-5

[66] HUANG MT, HO CT, WANG ZY, FERRARO T, LOU YR et al. Inhibition of skin tumorigenesis by rosemary and its constituents carnosol and ursolic acid. Cancer Res 1994; 54: 701-708.

[67] HO CT, FERRARO T, CHEN Q,ROSEN RT, HUANG MT, in Food Phytochem Cancer Prevention II: Teas, Spices and Herbs, ed. Ho CT, Osawa T, Huang MT, Rosen RT, ACS Symp. Ser. 547, American Chemical Society, Washington, DC, 1994; 2-19. http: //dx.doi.org/10.1021/bk-1994-0547.ch001

[68] ARUOMA OI, HALLIWELL B, AESCHBACH R, LOLIGERS $\mathrm{J}$ Antioxidant and pro-oxidant properties of active rosemary constituents: carnosol and carnosic acid. Xenobiotica 1992; 22: 257-268. http: //dx.doi.org/10.3109/00498259209046624

[69] ZEGURA B, DOBNIK D, NIDERL MH, FILIPIC M Antioxidant and antigenotoxic effects of rosemary (Rosmarinus officinalis L.) extracts in Salmonella typhimurium TA98 and HepG2 cells. Environ Toxicol Pharmacol 2011; 32: 296-305. http: //dx.doi.org/10.1016/j.etap.2011.06.002

[70] PARMAR J, SHARMA P, VERMA P, SHARMA P, GOYAL PK Anti-tumor and anti-oxidative activity of Rosmarinus officinalis in 7,12-dimethyl benz(a) anthracene induced skin carcinogenesis in mice. Am J Biomed Sci 2010; 3: 199-209.

[71] ANDERSON RF, AMARASINGHE C, FISHER LJ, Mak WB, PACKER JE Reduction in free-radical-induced DNA strand breaks and base damage through fast chemical repair by flavonoids. Free Radic Res 2000; 33: 91-103. http: //dx.doi. org/10.1080/10715760000300651

[72] FERGUSON LR, PHILPOTT M, KARUNASINGHE $\mathrm{N}$ Dietary cancer and prevention using antimutagens. Toxicology 2004; 198: 147-159. http: //dx.doi.org/10.1016/ j.tox.2004.01.035

[73] SLAMENOVA D, KUBOSKOVA K, HORVATHOVA E, ROBICHOVA S Rosemary-stimulated reduction of DNA strand breaks and FPG-sensitive sites in mammalian cells treated with $\mathrm{H} 2 \mathrm{O} 2$ or visible light-excited Methylene Blue. Cancer Lett 2002; 177: 145-53. http: //dx.doi.org/10.1016/S03043835(01)00784-4

[74] HORVATHOVA E, SLAMENOVA D, NAVAROVA J Administration of rosemary essential oil enhances resistance of rat hepatocytes against DNA-damaging oxidative agents. Food Chem 2010; 123: 151-156. http: //dx.doi.org/10.1016/ j.foodchem.2010.04.022

[75] YANG SA, JEON SK, LEE EJ, SHIM CH, LEE IS Comparative study of the chemical composition and antioxidant activity of six essential oils and their components. Nat Prod Res 2010; 24: 140-151. http: //dx.doi.org/10.1080/14786410802496598

[76] BILLANY MR, DENMAN S, JAMEEL S, SUGDEN JK Topical antirheumatic agents as hydroxyl radical scavengers. Internat J Pharm 1995; 124: 279-283. http: //dx.doi.org/10.1016/03785173(95)00099-5

[77] ECONOMOU KD, OREOPOULOU V, THOMOPOULOS CD Antioxidant activity of some plant extracts of the family Labiatae. J Am Oil Chem Society 1991; 68: 109-113. http: //dx.doi.org/10.1007/BF02662329
[78] AMR A, YOUSEF M A natural antioxidant from lavender (Lavandula officinalis Chaix). Dirasat Series B Pure \& App Scie 1995; 22: 1271-1288.

[79] HOHMANN J, ZUPKO I, REDEI D, CSANYI M, FALKAY G Protective effects of the aerial parts of Salvia officinalis, Melissa officinalis and Lavandula angustifolia and their constituents against enzyme-dependent and enzyme independent lipid peroxidation. Planta Med 1999; 65: 576-578. http: //dx.doi. org/10.1055/s-2006-960830

[80] BLAZEKOVIC B, KNEZEVIC SV, BRANTNER A, BIVAL MS Evaluation of antioxidant potential of Lavandula $\mathrm{x}$ intermedia Emeric ex Loisel. ,Budrovka': A comparative study with L.angustifolia Mill. Molecules 2010; 15: 5971-5987. http: //dx.doi.org/10.3390/molecules15095971

[81] MANOHARAN S, SINGH RB, BALAKRISHMAN $S$ Chemopreventive Mechanisms of Natural Products in Oral, Mammary and Skin Carcinogenesis: An Overview. Open Nutr J 2009; 2: 52-63. http: //dx.doi.org/10.2174/ 1876396000902010052

[82] FIORE G, NENCINI C, CAVALLO F, CAPASSO A, BADER $A$, et al. In vitro antiproliferative effect of six Salvia species on human tumor cell lines. Phytother Res 2006; 20: 701-703. http: //dx.doi.org/10.1002/ptr.1911

[83] DEEB SJ, EL-BABA CO, HASSAN SB, LARSSON RL, GALI-MUHTASIB HU Sage components enhance cell death through nuclear factor kappa-B signaling. Front Biosci 2011; 3: 410-20.

[84] SERTEL S, EICHHORN T, PLINKERT PK, EFFERTH T Anticancer activity of Salvia officinalis essential oil against HNSCC cell line (UMSCC1). HNO 2011; 59: 1203-1208. http: //dx.doi.org/10.1007/s00106-011-2274-3

[85] BAUER J, KUEHNL S, ROLLINGER JM, SCHERER O, NORTHOFF H, et al. Carnosol and carnosic acids from Salvia officinalis inhibit microsomal prostaglandin E2 synthase-1. J Pharmacol Exp Ther 2012; 342: 169-76. http: //dx.doi. org/10.1124/jpet.112.193847

[86] KOEBERLE A, SIEMONEIT U, BUHRING U, NORTHOFF H., LAUFER, S et al. Licofelone suppresses prostaglandin E2 formation by interference with the inducible microsomal prostaglandin E2 synthase-1. J Pharmacol Exp Ther 2008, 326: 975-982. http: //dx.doi.org/10.1124/jpet.108.139444

[87] KESHAVARZ M, BIDMESHKIPOUR A, MOSTAFAIE A, MANSOURI K, HAMID-REZA M Antitumor activity of Salvia officinalis is due to its anti-angiogenic, antimigratory and anti-proliferative effects. Cell J 2010; 12: 477-482.

[88] PLANK MJ, SLEEMAN BD Tumor-induced angiogenesis: A review. J Theor Med 2003; 5: 137-153. http: //dx.doi. org/10.1080/10273360410001700843

[89] LIMA CF, VALENTAO PC, ANDRADE PB, SEABRA, RM, FERNANDES-FERREIRA $M$, et al. Water and methanolic extracts of Salvia officinalis protect HepG2 cells from t-BHP induced oxidative damage. Chem-Biol Interact 2007; 167: 107-115. http: //dx.doi.org/10.1016/j.cbi.2007.01.020

[90] CASTELL JV, GOMEZ-LECHON MJ, PONSODA X, BORT $\mathrm{R}$ In vitro investigation of the molecular mechanisms of hepatotoxicity. In: Castell JV \& Gomez-Lechon MJ (Eds.), In Vitro 
Methods in Pharmaceutical Research, London, Academic Press, 1997, 375-410.

[91] BOZKURT E, ATMACA H, KISIM A, UZUNOGLU S, USLU R, et al. Effects of Thymus serpyllum extract on cell proliferation, apoptosis and epigenetic events in human breast cancer cells. Nutr Cancer 2012; 64: 1245-1250. http: //dx.doi. org/10.1080/01635581.2012.719658

[92] ZEYTINOGLU M, AYDIN S, OZTURK Y, BASER KHC Inhibitory effects of carvacrol on DMBA induced pulmonary tumorigenesis in rats. Acta Pharm Turcica 1998; 40: 93-98.

[93] HE L, MO H, HADISUSILU S, QURESNI AA, ELSON CE Isoprenoids supress the growth of murine B16 melanomas in vitro and in vivo. J Nutr 1997; 127: 668-674.

[94] KOPARAL AT, ZEYTINOGLU,M Effects of carvacrol on a human non- small cell lung cancer (NSCLC) cell line, A549. Cytotechnol. 2003; 43: 149-154. http: //dx.doi.org/10.1023/B: CYTO.0000039917.60348.45

[95] YOUDIM KA, DEANS SG Dietary supplementation of thyme (Thymus vulgaris L.) essential oil during the lifetime of the rat: its effects on the antioxidant status in liver, kidney and heart tissues. Mech Ageing Dev 1999; 109: 163-175. http: //dx.doi. org/10.1016/S0047-6374(99)00033-0

[96] THOMPSON CB Apoptosis in the pathogenesis and treatment of disease. Science 1995; 267: 1456-1462. http: //dx.doi. org/10.1126/science.7878464

[97] AGGARWAL BB, VAN KUIKEN ME, IYER LH, HARIKUMAR KB, SUNG B Molecular targets of nutraceuticals derived from dietary spices: potential role in suppression of inflammation and tumorigenesis. Exp Biol Med 2009; 234: 825-849. http: //dx.doi.org/10.3181/0902-MR-78

[98] THORNBERRY NA, LAZEBNIK Y Caspases: enemies within. Science 1998; 281: 1312-1316. http: //dx.doi.org/10.1126/ science.281.5381.1312

[99] FERRAZ RP, BOMFIM DS, CARVALHO NC, SOARES MB, DA SILVA TB et al. Cytotoxic effect of leaf essential oil of Lippia gracilis Schauer (Verbenaceae). Phytomedicine 2013; 20: 615-621. http: //dx.doi.org/10.1016/j.phymed.2013.01.015

[100] YIN QH, YAN FX, ZU XY, WU YH, WU XP et al. Antiproliferative and pro-apoptotic effect of carvacrol on human hepatocellular carcinoma cell line HepG-2. Cytotechnology 2012; 64: 43-51. http: //dx.doi.org/10.1007/s10616-011-9389-y

[101] VISANJI JM, THOMPSON DG, PADFIELD PJ Induction of G2/M phase cell cycle arrest by carnosol and carnosic acid is associated with alteration of cyclin A and cyclin B1 levels. Cancer Lett 2006; 237: 130-136. http: //dx.doi.org/10.1016/ j.canlet.2005.05.045

[102] AGGARWAL BB, GEHLOT P Inflammation and cancer: How friendly is the relationship for cancer patients? Curr Opin Pharmacol 2009; 9: 351-369. http: //dx.doi.org/10.1016/ j.coph.2009.06.020
[103] PARK C, MOON DO, RHU CH, CHOI BT, LEE WH et al. Beta-sitosterol induces anti-proliferation and apoptosis in human leukemic U937 cells through activation of caspase-3 and induction of Bax/Bcl-2 ratio. Biol Pharm Bull 2007; 30: 1317-1323. http: //dx.doi.org/10.1248/bpb.30.1317

[104] TAI J, CHEUNG S, WU M, HASMAN D Antiproliferation effect of Rosemary (Rosmarinus officinalis) on human ovarian cancer cells in vitro. Phytomedicine 2012; 19: 436-443. http: //dx.doi.org/10.1016/j.phymed.2011.12.012

[105] LOIZZO MR, TUNDIS R, MENICHINI F, SAAB AM, STATTI GA, et al. Antiproliferative effects of essential oils and their major constituents in human renal adenocarcinoma and amelanotic melanoma cells. Cell. Prolif 2008; 41: 1002-1012. http: //dx.doi.org/10.1111/j.13652184.2008.00561.X

[106] PAIK SY, KOH KH, BEAK SM, PAEK SH, KIM JA The essential oils from Zanthoxylum schinifolium pericarp induce apoptosis of HepG2 human hepatoma cells through increased production of reactive oxygen species. Biol Pharm Bull 2005; 28: 802-807. http: //dx.doi.org/10.1248/bpb.28.802

[107] GU Y, TING Z, QIU X, ZHANG X, GAN X et al. Linalool preferentially induces robust apoptosis of a variety of leukemia cells via upregulating p53 and cyclin-dependent kinase inhibitors. Toxicology 2010; 268: 19-24. http: //dx.doi. org/10.1016/j.tox.2009.11.013

[108] MIYASHITA M, SADZUKA Y Effect of linalool as a component of Humulus lupulus on doxorubicin-induced antitumor activity. Food Chem Toxicol 2013; 53: 174-179. http://dx.doi. org/10.1016/i.fct.2012.11.035

[109] LANTRY LE, ZHANG Z, GAO F, CRIST KA, WANG Yet al.Chemopreventive effect of perillyl alcohol on 4(methylnitrosamino)-1- (3pyridyl)-1-butanone induced tumorigenesis in $(\mathrm{C} 3 \mathrm{H} / \mathrm{HeJ} \mathrm{X} \mathrm{A} / \mathrm{J}) \mathrm{F} 1$ mouse lung. J Cell Biochem Suppl 1997; 27: 20-25. http: //dx.doi.org/10.1002/ (SICI) 1097-4644(1997)27+<20: : AID-JCB6>3.0.CO; 2-3

[110] REDDY BS, WANG CX, SAMAHA H, LUBET R, STEELE VE et al. Chemoprevention of colon carcinogenesis by dietary perillyl alcohol. Cancer Res 1997; 57: 420-425.

[111] ZIEGLER J Raloxifene, retinoids, and lavender: „me too“ tamoxifen alternatives under study. J Natl Cancer Inst 1996; 88: 1100-1102. http://dx.doi.org/10.1093/jnci/ $\underline{88.16 .1100}$

[112] CHERNG JM, SHIEH DE, CHIANG W Chemopreventive effects of minor dietary constituents in common foods on human cancer cells. Biosci Biotechnol Biochem 2007; 71: 1500-1504. http: //dx.doi.org/10.1271/bbb.70008

[113] GOULD MN, MALZMAN TH, TANNER MA, BOSTON JL, HURT LM et al. Anticarcinogenic effects of terpenoids in orange peel oil. Proc 78th Meeting Amer Assoc Cancer Res 1987; 28: 153. 